\title{
FLUORESCENT-STAINABLE ANTIBODIES TO THE EATON AGENT IN HUMAN PRIMARY ATYPICAL PNEUMONIA TRANSMISSION STUDIES *
}

\author{
By WALlaCE A. CLYDE, JR., † FLOYD W. DENNY and JOHN H. DINGLE \\ (From the Departments of Preventive Medicine, Medicine, and Pediatrics, School of Medicine, \\ Western Reserve University and the University Hospitals, Cleveland, Ohio)
}

(Submitted for publication February 20, 1961 ; accepted March 17, 1961)

The etiology of those cases of nonbacterial pneumonia that cannot be associated with the viruses of psittacosis and influenza, adenoviruses, or other well delineated agents, and in which cold hemagglutinins or streptococcus MG agglutinins often develop, has been a controversial subject. The possible role in this disease of an agent isolated by Eaton, Meiklejohn, van Herick and Talbot in 1941 from patients with primary atypical pneumonia (1) has been difficult to evaluate because of the agent's limited host range and technical problems in performing specific serologic tests with it. Eaton's agent can be propagated in embryonated hens' eggs, as demonstrated by production of pneumonia on passage to cotton rats (2), but produces no apparent pathologic change in the chick embryo $(2,3)$. Using a modification of the fluorescent antibody technique of Coons and Kaplan (4), Liu, Eaton and Heyl have provided both a means of localizing the antigens in the chick embryo and a method by which sera can be examined for fluorescent-stainable antibodies to Eaton's agent $(3,5)$. Additional isolations of Eaton's agent from patients and demonstrations of fluorescent-stainable antibodies to it have been reported by Cook (6) and Chanock (7) and their associates, confirming and extending the observations of Eaton and Liu. The specificity of this fluorescent antibody reaction in terms of the etiology of the disease has been questioned (8), however, since patients with primary atypical pneumonia may develop a number of nonspecific

* This investigation was conducted under the sponsorship of the Commission on Acute Respiratory Diseases, Armed Forces Epidemiological Board, and was supported in part by the Office of The Surgeon General, Department of the Army, and by a grant from the Robert Hamilton Bishop, Jr., Endowment Fund.

$\dagger$ This investigation was carried out during the tenure of a Postdoctoral Fellowship from the National Institute of Allergy and Infectious Diseases. serologic responses (9-15). Primary atypical pneumonia produced under experimental conditions in man would provide an ideal situation for comparison of these various serologic tests.

In 1944 the Commission on Acute Respiratory Diseases of the Armed Forces Epidemiological Board performed studies on the transmission of primary atypical pneumonia to human subjects, using sputa and throat washings from patients with the characteristic syndrome (16a-d). Among the volunteers inoculated, two distinct disease patterns were induced:1) an illness with constitutional symptoms and physical and roentgenographic findings of primary atypical pneumonia, and 2) a minor respiratory illness with minimal constitutional symptoms and physical findings but without pulmonary infiltration. Two similar experiments were performed, those men developing primary atypical pneumonia in the first experiment serving as donors of inocula for the second. Most of the cases of primary atypical pneumonia and a few cases of the milder respiratory illness were associated with rises of cold hemagglutinins. The study suggested the presence of a filtrable, transmissible agent associated with the induced disease, but none was isolated by methods then available.

Further information on the association of Eaton's agent with human disease has been afforded by application of Liu's techniques to preserved sera from participants in the above transmission studies. Significant rises of fluorescent-stainable antibodies to Eaton's agent occurred in the majority of inoculated volunteers' sera. The data obtained are presented in this report.

\section{MATERIALS AND METHODS}

Eaton's agent. The Mac strain of Eaton's agent (17) was used throughout the experiments, and seed material was kindly supplied in the form of infected chick embryo 
TABLE I

Summary of clinical and serological data, first primary atypical pneumonia volunieer experiment

\begin{tabular}{|c|c|c|c|c|c|c|c|c|}
\hline \multirow[b]{4}{*}{ Inoculum } & \multirow[b]{4}{*}{$\begin{array}{l}\text { Case } \\
\text { no.* }\end{array}$} & \multirow[b]{4}{*}{$\begin{array}{c}\text { Disease } \\
\text { inducedt }\end{array}$} & \multirow{4}{*}{$\begin{array}{l}\text { Incu- } \\
\text { bation } \\
\text { period }\end{array}$} & \multirow[b]{4}{*}{$\begin{array}{l}\text { Severity of } \\
\text { illness }\end{array}$} & \multirow[b]{4}{*}{$\begin{array}{c}\text { Cold hemagglut. } \\
\text { (max. titers) } \delta\end{array}$} & \multicolumn{3}{|c|}{ Serological data $\|$} \\
\hline & & & & & & \multicolumn{3}{|c|}{ Fluorescent-stainable antibody } \\
\hline & & & & & & \multirow[b]{2}{*}{ Pre-inoc. } & \multicolumn{2}{|c|}{ Postinoculation } \\
\hline & & & & & & & Titer & $\begin{array}{l}\text { Day } \\
\text { bled }\end{array}$ \\
\hline \multirow{2}{*}{ Untreated } & & & days & & & & & \\
\hline & $\begin{array}{l}4 ף \\
9 \\
11 \\
13 \\
15 \\
28 \\
30 \\
31 \\
32 \\
34 \\
429 \\
449\end{array}$ & $\begin{array}{l}\text { PAP } \\
\text { MRI } \\
\text { MRI } \\
\text { MRI } \\
\text { MRI } \\
\text { MRI } \\
\text { MRI } \\
\text { MRI } \\
\text { MRI } \\
\text { MRI } \\
\text { PAP } \\
\text { PAP }\end{array}$ & $\begin{array}{l}8 \\
4 \\
4 \\
6 \\
3 \\
1 \\
2 \\
6 \\
1 \\
1 \\
1 \\
8\end{array}$ & $\begin{array}{l}\text { Severe } \\
\text { Mild } \\
\text { Mild } \\
\text { Mild } \\
\text { Mild } \\
\text { Mild } \\
\text { Mild } \\
\text { Mild } \\
\text { Mild } \\
\text { Mild } \\
\text { Moderate } \\
\text { Moderate }\end{array}$ & $\begin{array}{c}512^{* *} \\
<8 \\
<8 \\
16 \\
<8 \\
8 \\
<8 \\
<8 \\
<8 \\
8 \\
32 \\
2,048\end{array}$ & $\begin{array}{l}10 \\
\text { N.A. } \\
<10 \\
<10 \\
<10 \\
320 \\
10 \\
<10 \\
<10 \\
10 \\
\text { N.A. } \\
<10 \dagger t\end{array}$ & $\begin{array}{r}320 \\
\text { N.A. } \\
80 \\
40 \\
20 \\
320 \\
20 \\
<10 \\
160 \\
20 \\
\text { N.A. } \\
<10 \dagger \dagger\end{array}$ & $\begin{array}{l}32 \\
15 \\
25 \\
18 \\
25 \\
28 \\
25 \\
25 \\
28 \\
\\
18\end{array}$ \\
\hline Filtered & $\begin{array}{l}2 \rrbracket \\
7 \\
14 \\
17 \\
20 \\
249 \\
25 \\
27 \\
29 \\
33 \\
35 \\
45 \pi\end{array}$ & $\begin{array}{l}\text { PAP } \\
0 \\
\text { MRI } \\
0 \\
0 \\
\text { PAP } \\
\text { PAP } \\
\text { MRI } \\
\text { MRI } \\
\text { MRI } \\
\text { MRI } \\
\text { PAP }\end{array}$ & $\begin{array}{r}9 \\
12 \\
10 \\
11 \\
9 \\
7 \\
12\end{array}$ & $\begin{array}{l}\text { Moderate } \\
\text { Severe } \\
\text { Moderate } \\
\text { Mild } \\
\text { Mild } \\
\text { Mild } \\
\text { Mild } \\
\text { Mod. severe }\end{array}$ & $\begin{array}{r}16 \\
<8 \\
8 \\
<8 \\
<8 \\
512 \\
<8 \\
<8 \\
<8 \\
<8 \\
8 \\
256^{* *}\end{array}$ & $\begin{array}{l}\text { N.A. } \\
<10 \\
10 \\
<10 \\
<10 \\
<10 \\
<10 \\
<10 \\
\text { N.A. } \\
<10 \\
<10 \\
<10\end{array}$ & $\begin{array}{r}\text { N.A. } \\
80 \\
10 \\
<10 \\
40 \\
<10 \\
<10 \\
80 \\
\text { N.A. } \\
<10 \\
20 \\
320\end{array}$ & $\begin{array}{l}25 \\
25 \\
28 \\
18 \\
32 \\
28 \\
18 \\
\\
25 \\
25 \\
32\end{array}$ \\
\hline Autoclaved & $\begin{array}{r}1 \\
3 \\
5 \\
6 \\
10 \\
16 \\
18 \\
19 \\
22 \\
26 \\
46 \\
47\end{array}$ & $\begin{array}{c}0 \\
0 \\
\text { PAP } \\
0 \\
0 \\
0 \\
0 \\
0 \\
\text { MRI } \\
0 \\
\text { PAP } \\
\text { PAP }\end{array}$ & $\begin{array}{r}7 \\
10 \\
10\end{array}$ & $\begin{array}{l}\text { Mild } \\
\text { Moderate } \\
\text { Moderate }\end{array}$ & $\begin{array}{l}<8 \\
<8 \\
16 \\
<8 \\
<8 \\
<8 \\
<8 \\
<8 \\
<8 \\
<8 \\
<8 \\
32\end{array}$ & $\begin{aligned} & 20 \\
&<10 \\
&<10 \\
&<10 \\
&<10 \\
&<10 \\
&<10 \\
& \text { N.A. } \\
&<8 \\
&<10 \\
&<10 \\
& 10 \dagger \dagger\end{aligned}$ & $\begin{array}{c}10 \\
20 \\
40 \\
<10 \\
<10 \\
<10 \\
40 \\
\text { N.A. } \\
320 \\
10 \\
10 \\
160 \dagger \dagger\end{array}$ & $\begin{array}{l}28 \\
32 \\
32 \\
28 \\
25 \\
25 \\
25 \\
\\
18 \\
28 \\
18 \\
32\end{array}$ \\
\hline
\end{tabular}

* Case numbers refer to those from the original volunteer experiments (Ref. 16a-d).

+ Diseases: PAP $=$ primary atypical pneunonia ; MRI = minor respiratory illness; $0=$ no illness (see text).

$\ddagger$ Time between inoculation and first symptoms.

$\$$ Maximal cold hemagglutinin titer obtained in weekly tests after inoculation; pre-inoculation titers all $<8$ unless otherwise specified.

$\|$ N.A. = sera not available.

If Donors of inocula for the second volunteer experiment.

** All these cases developed streptococcus MG agglutinin titers of 32 (from <8).

t† Titrations performed by Dr. C. Liu.

lung suspension by Dr. Chien Liu. The agent was propagated by amniotic stab inoculation of 14-day old chick embryos with $0.2 \mathrm{ml}$ each of a 1:5 dilution of seed material in brain-heart infusion broth (Difco) and 1 per cent bovine albumin (Armour). For the first two passages $1,000 \mathrm{U}$ of penicillin was added per $\mathrm{ml}$ of lung suspension. After 5 days' incubation at $35^{\circ} \mathrm{C}$, inoculated embryos were harvested without chilling, and the lungs and trachea of each were removed aseptically. Tissues were ground in $2 \mathrm{ml}$ of the broth-bovine albumin mixture per specimen in a glass tissue grinder. The pooled crude suspension was divided into $1-$ to $2-\mathrm{ml}$ aliquots, sealed in glass ampules, and stored at $-70^{\circ} \mathrm{C}$. Material used in the experiments to follow was from the sixth egg passage, having an infectivity titer of $10^{6} \mathrm{EID}_{50}$ per $0.2 \mathrm{ml}$, as determined by methods described by Liu (3). 
Eggs. White Leghorn eggs from a local source were used exclusively. These were placed in a commercialtype incubator-hatcher for 14 days and after inoculation were maintained in a humidified standard laboratory incubator.

Sera. Sera collected before and after inoculation (see Tables I and II, and References 16a-d) of the volunteers were stored at $4^{\circ} \mathrm{C}$ for 12 to 18 months before lyophilization. They were then kept at room temperature for about 8 years and were subsequently stored at $4^{\circ} \mathrm{C}$. Sera from
70 of the original 78 participants were available for examination. Each specimen was reconstituted to the original volume by addition of $2 \mathrm{ml}$ of sterile distilled water, and aliquots were removed for testing. Sera from patients with primary atypical pneumonia in the Cleveland area (18), stored at $-20^{\circ} \mathrm{C}$ since 1947 , provided positive and negative control specimens. Results of previous titrations of these control sera have been published by Cook and co-workers (6).

For the preparation of fluorescein isothiocyanate-con-

TABLE II

Summary of clinical and serological data, second primary atypical pneumonia volunteer experiment *

\begin{tabular}{|c|c|c|c|c|c|c|c|c|}
\hline \multirow[b]{4}{*}{ Inoculum } & \multirow[b]{4}{*}{$\begin{array}{l}\text { Case } \\
\text { no. }\end{array}$} & \multirow[b]{4}{*}{$\begin{array}{l}\text { Disease } \\
\text { induced }\end{array}$} & \multirow{4}{*}{$\begin{array}{l}\text { Incu- } \\
\text { bation } \\
\text { period }\end{array}$} & \multirow[b]{4}{*}{$\begin{array}{l}\text { Severity of } \\
\text { illness }\end{array}$} & \multicolumn{4}{|c|}{ Serological data } \\
\hline & & & & & \multirow[b]{3}{*}{$\begin{array}{c}\text { Cold hemagglut. } \\
\text { (max. titers) }\end{array}$} & \multicolumn{3}{|c|}{ Fluorescent-stainable antibody } \\
\hline & & & & & & \multirow[b]{2}{*}{ Pre-inoc. } & \multicolumn{2}{|c|}{ Postinoculation } \\
\hline & & & & & & & Titer & $\begin{array}{l}\text { Day } \\
\text { bled }\end{array}$ \\
\hline \multirow{13}{*}{ Untreated } & & & days & & & & & \\
\hline & 101 & 0 & & & $<8$ & $<10$ & 160 & 32 \\
\hline & 103 & MRI & 6 & Mild & 128 & $<10$ & 160 & 21 \\
\hline & 111 & 0 & & & $<8$ & 10 & 160 & 29 \\
\hline & 112 & PAP & 7 & Mod. severe & 512 & $<10 \dagger \dagger$ & $<10+\dagger$ & 42 \\
\hline & 126 & 0 & & & $<8$ & 10 & 20 & 42 \\
\hline & 127 & MRI & 6 & Mild & 32 & N.A. & N.A. & \\
\hline & 129 & MRI & 7 & Mild & $16^{* *}$ & $<10$ & 640 & 29 \\
\hline & 131 & MRI & 4 & Moderate & 256 & N.A. & N.A. & \\
\hline & 132 & 0 & & & 16 & 10 & 40 & 46 \\
\hline & 137 & PAP & 8 & Severe & 8,192 & $<10$ & 320 & 73 \\
\hline & 138 & MRI & 7 & Moderate & 16 & $<10$ & 80 & 21 \\
\hline & 158 & PAP & 7 & Moderate & $<8$ & $<10$ & 80 & 29 \\
\hline \multirow[t]{12}{*}{ Filtered } & & & & & & & & \\
\hline & 105 & PAP & 14 & Moderate & 1,024 & $<10$ & 160 & 21 \\
\hline & 110 & MRI & 15 & Mild & 64 (pre-inoc. 8) & 80 & 320 & 42 \\
\hline & 113 & MRI & 10 & Mild & $<8$ & $<10$ & 40 & 29 \\
\hline & 120 & 0 & & & $<8$ & $<10$ & 40 & 29 \\
\hline & 124 & MRI & 9 & Moderate & 8 & $<10$ & 80 & 46 \\
\hline & 130 & MRI & 12 & Mild & 16 & $<10$ & 80 & 43 \\
\hline & 134 & MRI & 12 & Moderate & 64 & $<10$ & 20 & 65 \\
\hline & 136 & 0 & & & $<8$ & $<10$ & $<10$ & 29 \\
\hline & 142 & 0 & & & $<8$ & $<10$ & 40 & 21 \\
\hline & 144 & PAP & 13 & Moderate & 128 & $<10 \dagger \dagger$ & $80+t$ & 29 \\
\hline & 146 & PAP & 12 & Moderate & 1,024 & $<10$ & 20 & 50 \\
\hline \multirow{20}{*}{ Autoclaved } & & & & & & & & \\
\hline & 102 & MRI & 19 & Mild & 32 & N.A. & N.A. & \\
\hline & 106 & 0 & & & $<8$ & 20 & 20 & 41 \\
\hline & 107 & 0 & & & $<8$ & 20 & 20 & 42 \\
\hline & 108 & 0 & & & $<8$ & $<10$ & 10 & 20 \\
\hline & 109 & 0 & & & $<8$ & $<10$ & $<10$ & 27 \\
\hline & 115 & 0 & & & $<8$ & 20 & 10 & 46 \\
\hline & 116 & 0 & & & $<8$ & $<10$ & $<10$ & 27 \\
\hline & 117 & 0 & & & $>32($ pre-inoc. 8$)$ & 20 & 80 & 29 \\
\hline & 118 & 0 & & & $<8$ & 10 & 10 & 43 \\
\hline & 119 & 0 & & & $<8$ & 40 & 40 & 29 \\
\hline & 120 & 0 & & & $<8$ & $<10$ & 40 & 29 \\
\hline & 121 & 0 & & & $<8$ & $<10$ & $<10$ & 29 \\
\hline & 125 & 0 & & & $<8$ & $<10$ & 20 & 43 \\
\hline & 133 & 0 & & & $<8$ & $<10$ & 20 & 43 \\
\hline & 135 & 0 & & & $<8$ & $<10$ & $<10$ & 42 \\
\hline & 139 & 0 & & & $<8$ & $<10$ & 10 & 21 \\
\hline & 140 & 0 & & & 8 & 10 & 20 & 43 \\
\hline & 141 & 0 & & & $<8$ & $<10$ & $<10$ & 43 \\
\hline & 143 & 0 & & & $<8$ & $<10$ & 20 & 43 \\
\hline
\end{tabular}

* See footnotes to Table I. 
jugated antisera, adult goats were immunized by weekly subcutaneous injections of pooled human globulins with aluminum hydroxide as adjuvant. Injections were continued until the undiluted serum produced a precipitin reaction with antigen dilutions of $10^{-4}$ or greater.

Fluorescein-conjugated antihuman globulin solution. The globulin fraction of the goat antihuman serum was precipitated with $\left(\mathrm{NH}_{4}\right)_{2} \mathrm{SO}_{4}$ by standard methods (19). The globulin solution was conjugated with fluorescein isothiocyanate $(20)^{1}$ by the technique of Marshall, Eveland and Smith (21). The final product contained 1 per cent protein and $0.05 \mathrm{mg}$ fluorescein isothiocyanate per $\mathrm{mg}$ of protein. After dialysis against phosphate-buffered saline $(0.01 \mathrm{M}, \mathrm{pH} 7.2)$ for 7 to 8 days to remove uncombined fluorescein, the labeled globulin solution was absorbed once each with acetone-extracted chick embryo and adult chicken lung powders (4) to remove nonspecific staining properties. The absorbed, conjugated globulin solution was stored at $-25^{\circ} \mathrm{C}$ until needed.

Fluorescent microscopic equipment. The source of ultraviolet light was an AH-6 water-cooled mercury vapor lamp, ${ }^{2}$ filtered by a $2.5 \mathrm{~cm}$ path of 2.5 per cent $\mathrm{CuSO}_{4} \cdot 5 \mathrm{H}_{2} \mathrm{O}$ solution and a half-thickness Corning 5840 filter. A standard laboratory monocular microscope was employed, fitted with a cardioid dark field condenser and a double Wratten 2-A gelatin filter in the ocular.

Preparation of infected tissuc for scrum titrations. Chick embryos were inoculated with stock virus suspension and harvested as described above. The thorax of each embryo was removed, placed in an individual rubberstoppered tube and quick-frozen in an ethanol-carbon dioxide ice bath. In a microtome cryostat ${ }^{3} 4-\mu$ frozen sections of the lungs of each embryo were cut. These were examined for viral antigens by the indirect fluorescent antibody technique, with known positive human convalescent serum and goat antihuman fluorescein-conjugated globulin solution. Embryos showing maximal (4+) fluorescence of the bronchial epithelium in two or more foci were selected for future use. Series of such sections were prepared for titrations, dried at room temperature, and stored at $4^{\circ} \mathrm{C}$ until used (within 1 week). Several hundred sections from each specimen could be obtained. If screening revealed antigen in the first and last sections of a consecutive series, those between were assumed to be positive.

Serum titrations. Fluorescent-stainable antibodies were titrated by a modification of the technique of Weller and Coons (22) as described by Liu and co-workers (5). Simultaneous titrations were performed, using sections from the same chick embryo, on pre- and postinoculation sera of a given individual. Sera were first inactivated by heating at $56^{\circ} \mathrm{C}$ for 30 minutes. Dilutions were prepared in an ice bath; the diluent was 1:20 fresh human serum, free from stainable antibodies to the Eaton agent, in phosphate-buffered saline. Sera negative at a screening dilution of 1:10 were not further evaluated, while

1 Dajac Labs., Borden Chemical Co., Philadelphia, Pa.

2 General Electric Co., Cleveland, Ohio.

${ }^{3}$ Harris Refrigeration Co., Cambridge, Mass. lhose positive were diluted in twofold increments to $1: 1,280$ for testing on the same day. Each serum dilution tube received a code number and was not further identified until completion of the titration experiments. In addition, all titrations were performed without knowledge by the observer of the volunteer's classifications.

Indirect fluorescent antibody technique. The entire staining procedure was conducted at room temperature. Series of infected chick embryo lung sections were fixed in acetone for 10 minutes and dried at $36^{\circ} \mathrm{C}$ for $20 \mathrm{~min}$ utes. Each section was overlaid with one serum dilution for 30 minutes. Slides were washed with gentle agitation in buffered saline for 10 minutes, wiped dry except for the section, and a drop of goat antihuman fluorescein-conjugated globulin solution applied for 30 minutes. The slides were again washed in buffered saline and mounted in buffered glycerol. The sections were examined under a fluorescence microscope and the amount of fluorescence recorded as 1 to $4+$. Titration endpoints were determined as those serum dilutions giving minimal (1+) fluorescence of the chick bronchial epithelium.

Titration and staining controls. Dilutions of $1: 10$, $1: 100$, and $1: 1,000$ of a serum with a consistent titer of 1,280 were included in each series of titrations to indicate the range and reproducibility of positive reactions. In addition to the positive serum, the following controls were included in each series of titrations with identical processing: 1) the first and last sections from each consecutive series used, stained with a 1:10 dilution of positive control serum; 2) sections stained with the serum diluent (1:20 fresh known-negative human serum in buffered saline); and 3) sections held in buffered saline during the serum-staining period.

\section{RESULTS}

Detailed reports of the original experiments, which were designed to evaluate the nature of the etiological factors and clinical characteristics of primary atypical pneumonia, have been published previously (16a-d). A brief summary of these experiments is included here, however, for its pertinence to the material to follow.

First experiment (Table I). Pooled sputa and throat washings from 6 patients with primary atypical pneumonia were divided into 3 aliquots which were respectively autoclaved, filtered to remove bacteria, and retained untreated. Three groups of volunteers, totaling 37 individuals, each received one of the types of inocula by nasopharyngeal insufflation, those inoculated with autoclaved material serving as the control group. Ten cases of primary atypical pneumonia and 15 cases of an undifferentiated minor respiratory illness resulted. These findings were difficult to interpret because both disease syndromes occurred in the control group. A modified repetition of this study was performed for further evaluation. 
Sccond cxperiment (Table II). Inoculum was obtained from 6 of the more severe cases of primary atypical pneumonia which had been induced in the first experiment, and aliquots were again autoclaved, filtered, and retained untreated. In addition to more rigorous isolation procedures, the inoculations were performed outdoors and on different days, beginning with the autoclaved material and concluding with the untreated pool. Six cases of primary atypical pneumonia and 10 cases of minor respiratory illness developed in the 24 men who received untreated or filtered inocula. No clinical illnesses developed in the control group except in one volunteer (Case 102) who violated isolation restrictions by visiting a patient with minor respiratory illness (Case 138).

The original serological data from the two experiments are summarized in Tables I and II. Fourfold or greater responses of cold hemagglutinins occurred in the donors of inocula, in most of the volunteers developing primary atypical pneumonia, and in a few of those with minor respiratory illness. Streptococcus $\mathrm{MG}$ agglutinin responses occurred rarely.

The introduction of a new serological procedure for the study of primary atypical pneumonia made it possible to re-evaluate these data, and in so doing to expand information concerning the nature of the test itself. The significance of the results of fluorescent-stainable antibody titrations on the sera from the volunteers was judged by: 1) correlation with the types of inocula administered;2) correlation with the occurrence of induced illness; and 3) comparison with the previously reported results of cold hemagglutinin and streptococcus MG agglutinin tests performed on the same sera.

The data obtained revealed an association between illness and the development of fluorescentstainable antibody to Eaton's agent. In addition, a number of volunteers who remained well after inoculation and failed to show cold hemagglutinins or streptococcus MG agglutinins developed these antibodies. Certain discrepancies concerning the development of illness and antibody responses will be detailed and discussed.

Relationship of fuorescent-stainable antibody responses to types of inocula. The correlation between the nature of the inoculating material and the fluorescent-stainable antibody responses provided one method of assessing the significance of the results obtained. The outcome of inoculation with filtered or untreated material was similar in both experiments; therefore, these groups have been combined for presentation, as indicated in Table III. Sixty-eight per cent of those receiving filtered inocula and 65 per cent of those receiving untreated inocula developed fourfold or greater rises of fluorescent-stainable antibody. The mean antibody response of the former group was a 10 -fold increase, while that of the latter was a 21.9-fold increase. It was previously noted that those men receiving filtered inocula had somewhat milder illnesses after longer incubation periods, which was thought to be due to a reduction of the inoculating dose occasioned by the filtration procedure (16c) (Tables I and II).

In the first transmission experiment, three cases of primary atypical pneumonia and one of minor respiratory illness developed in the group receiving autoclaved inoculum. These unexpected illnesses were clinically and serologically identical with those induced in volunteers given active (filtered and untreated) inocula (Tables I and II). In view of the absence of apparent disease in the control group of the second experiment, it was felt that the illnesses in the first instance were produced by inadvertent infection rather than by stimulation of a theoretical latent agent by the inoculation procedure (16b). Possible mechanisms involved have been previously discussed (16b), and included contamination of the airpump used for insufflation of inocula, airborne spread at the time of inoculation, or cross-infection after inoculation. The second possibility was favored by the occurrence of primary atypical pneumonia in an attendant and two members of the professional staff involved.

Since inadvertent infection apparently occurred in the first control group, this has been excluded from the comparative data to be presented. Of the 17 control subjects with available sera from the second experiment, 3 developed 2 -fold anti-

TABLE III

Relationship of fluorescent-stainable antibody responses to types of inocula received by 59 volunteers

\begin{tabular}{lcccc}
\hline \hline $\begin{array}{c}\text { Type of } \\
\text { inoculum }\end{array}$ & Cases & 4-Fold or >rise & $\begin{array}{c}\text { Mean } \\
\text { rise of } \\
\text { titer* }\end{array}$ \\
\hline & no. & no. & $\%$ & fold \\
Autoclaved $\dagger$ & 17 & 4 & 23.5 & 1.3 \\
Filtered $\ddagger$ & 22 & 15 & 68.2 & 10.0 \\
Untreated $\ddagger$ & 20 & 13 & 65.0 & 21.9 \\
\hline
\end{tabular}

* Average-fold change based on the responses of all individuals in each group.

$\dagger$ Control group of second experiment.

$\ddagger$ Combined groups from first and second experiments. 
body rises, and 4 showed 4 -fold rises, giving a mean response for the group of 1.3-fold (Table III). In one of the latter instances (Case 117, Table II), the cold hemagglutinin titer began to rise 2 weeks prior to inoculation, suggesting an unassociated infection. Using the rank-sum method (23), the differences in mean responses of the groups receiving either filtered or untreated inocula, compared with the control group of the second experiment, were found to be statistically significant $(p<0.01)$. The difference between the groups receiving filtered or untreated inocula was not significant.

Relationship of fluorescent-stainable antibody responses to the volunteers' postinoculation diagnoses. The manifestations of the two types of induced illnesses have been detailed previously (16c) and are outlined briefly above. The cases of primary atypical pneumonia followed an incubation period of 7 to 14 days, while the undifferentiated minor respiratory illneses had a more variable incubation period of 1 to 19 days. The possibility that these two clinical entities may have been caused by different etiologic agents was neither confirmed nor disproved by the original data (16b). Results from the present study made possible further evaluation of this problem.

Fourfold or greater rises of fluorescent-stainable antibody to Eaton's agent developed in the sera of 21 of 31 individuals who became clinically ill after receiving active inocula (Table IV). These included 7 of 11 cases of primary atypical pneumonia and 14 of 20 cases of minor respiratory illness occurring in the two transmission experiments. Seven of 11 men who remained well after
TABLE IV

Relationship of fluorescent-stainable antibody responses to diagnosis in 42 volunteers given active inocula

\begin{tabular}{lcccc}
\hline \hline \multicolumn{1}{c}{ Diagnosis* } & Cases & \multicolumn{2}{c}{$\begin{array}{c}\text { 4-Fold or } \\
\text { >rise }\end{array}$} & $\begin{array}{c}\text { Mean } \\
\text { rise of } \\
\text { titer }\end{array}$ \\
\hline & no. & no. & $\%$ & fold \\
Primary atypical pneumonia & 11 & 7 & 63.6 & 24.0 \\
Minor respiratory illness & 20 & 14 & 70.0 & 15.4 \\
No illness & 11 & 7 & 63.6 & 8.5 \\
\hline
\end{tabular}

* Clinical diagnosis by criteria listed in the text.

inoculation also developed significant rises. All of the patients with primary atypical pneumonia had pre-inoculation antibody levels of less than 10, while among those developing minor respira- . tory illness, two had baseline titers of 10 , one of 80 , and one of 320 . In the group remaining well, three volunteers had pre-inoculation titers of 10 and one of 20 (Tables I and II).

No essential differences in the percentage of significant responses occurred among the ill and the well groups (Table IV). Calculation of mean increases of titer revealed that the response of the primary atypical pneumonia group was 24-fold; that of the minot respiratory illness group, 15.4fold; and that of the group without illness, 8.5fold. While these figures represent a progressive trend, the differences between groups are not statistically significant when tested with the ranksum method ( $p>0.05)$.

Relationship of fuorescent-stainable antibody responses to cold hemagglutinins and streptococcus $M G$ agglutinins. It has been shown that cold hemagglutinin responses in primary atypical pneumonia bear a direct relationship to the severity and

TABLE V

Relationship of antibody responses to the severity of disease among 42 subjects receiving active inoculum

\begin{tabular}{|c|c|c|c|c|c|c|c|}
\hline \multirow[b]{2}{*}{$\begin{array}{l}\text { Degree of } \\
\text { illness* }\end{array}$} & \multirow[b]{2}{*}{ Cases } & \multicolumn{3}{|c|}{ Fluorescent-stainable antibody } & \multicolumn{3}{|c|}{ Cold hemagglutinins } \\
\hline & & \multicolumn{2}{|c|}{ 4-Fold or $>$ rise } & \multirow{2}{*}{$\begin{array}{c}\begin{array}{c}\text { Mean } \\
\text { rise }\end{array} \\
\text { fold }\end{array}$} & \multicolumn{2}{|c|}{ 4-Fold or $>$ rise } & \multirow{2}{*}{$\begin{array}{c}\begin{array}{c}\text { Mean } \\
\text { rise }\end{array} \\
\text { fold }\end{array}$} \\
\hline & no. & no. & $\%$ & & no. & $\%$ & \\
\hline Not ill $\dagger$ & 11 & 7 & 63.6 & 8.5 & 0 & 0.0 & 0.0 \\
\hline Mild $\ddagger$ & 17 & 11 & 64.7 & 16.0 & 5 & 29.4 & 3.9 \\
\hline Moderate§ & 8 & 6 & 75.0 & 12.5 & 5 & 62.5 & 102.8 \\
\hline Severe\| & 6 & 4 & 66.7 & 32.7 & 6 & 100.0 & 458.7 \\
\hline
\end{tabular}

* Based upon clinical appraisal, extent of pulmonary infiltration, and duration of illness.

+ Patients without clinical disease.

$\$$ Patients with an undifferentiated minor respiratory illness.

$\$$ Patients with febrile respiratory disease and rales without pulmonary infiltration demonstrable radiographically, and cases of mild primary atypical pneumonia.

II Patients with moderately severe and severe primary atypical pneumonia. 
TABLE VI

Correlation between responses of both fluorescent-stainable antibody and cold hemagglutinins in the sera of 42 volunteers

\begin{tabular}{ccc} 
& \multicolumn{2}{c}{$\begin{array}{c}\text { Fluorescent-stain- } \\
\text { able antibody }\end{array}$} \\
\cline { 2 - 3 } Cold hemagglut. & Present* & Absent† \\
\hline Present* & 15 & 3 \\
Absent $\dagger$ & 13 & 11 \\
\hline
\end{tabular}

* Fourfold or $>$ titer rise.

$\dagger$ Fourfold titer rise.

duration of illness $(9,13)$. That this was the case in the studies under consideration is illustrated in Table V. Volunteers with more severe

- illnesses demonstrated both a higher level and a greater percentage of cold hemagglutinin rises. The development of fluorescent-stainable antibody did not follow this pattern in occurrence, roughly two-thirds of volunteers in all clinical categories having fourfold or greater antibody responses. There was a trend toward higher titers in those men with the more severe illnesses, as shown by comparison of mean antibody increases for the same groups, but these differences were not statistically significant.

The correlation between the development of cold hemagglutinins and fluorescent-stainable antibodies in the same sera is illustrated in Table VI. Fourfold or greater cold hemagglutinin responses occurred in 18 (43 per cent) of 42 individuals receiving active inocula. Of these 18 patients having significant cold hemagglutinin responses, 15 ( 82 per cent) also had rises of fluorescent-stainable antibody; however, of the 28 with significant fluorescent-stainable antibody rises, only 15 (54 per cent) had cold hemagglutinin responses. Rises of streptococcus MG agglutinins, all sixfold, occurred in two patients with primary atypical pneumonia and in one with minor respiratory illness. Significant responses of both cold hemagglutinins and fluorescent-stainable antibody developed in these same patients. No detectable antibody responses occurred in 11 of the 42 volunteers (26 per cent), including 4 without illness, 6 with minor respiratory illness, and 1 with primary atypical pneumonia.

\section{DISCUSSION}

Although the identity of the infectious agent involved in the experiments is unknown, the rises in titer of fluorescent-stainable antibody to the Eaton agent were striking. Interpretation of the data is complicated by the present lack of knowledge of the nature of these fluorescent-stainable antibodies. Patients with primary atypical pneumonia may develop a variety of abnormal serologic reactions during convalescence: agglutinins for group $\mathrm{O}$ erythrocytes in the cold; agglutinins for streptococcus MG; complement-fixing reactions for various heterologous tissue antigens; and even false serologic tests for syphilis (8-15). Liu and associates, by means of cross-absorption experiments, demonstrated that the fluorescent-stainable antibodies are distinct from cold hemagglutinins and streptococcus MG agglutinins (5). The antigen-fluorescent-stainable antibody reaction does not bind complement but is enhanced by the presence of a heat-labile factor in normal fresh serum $(5,24)$. Except in rare instances (25), sera containing these antibodies fail to neutralize Eaton's agent in eggs; but Eaton has shown that sera of patients with primary atypical pneumonia may neutralize the agent, as indicated by prevention of pneumonia in cotton rats or hamsters inoculated with serum-virus mixtures (26, 27). Results of both fluorescent-stainable antibody titrations and cotton rat neutralization titrations on the same sera reveal a close correlation in development of the two $(5,28)$. The data presented above suggest that the presence of fluorescent-stainable antibodies did not provide complete protection from induction of disease in man, although modification of disease may have occurred in those individuals who had pre-existing antibody at a measurable level. The data from this series are quite limited, but none of the individuals receiving active inocula who developed primary atypical pneumonia had a baseline titer of 10 or greater, while several of those developing minor respiratory illness or remaining well had baseline titers above this range.

Certain discrepancies occurred in the experimental data which are difficult to interpret. Although the control group of the second experiment appeared adequate, fluorescent-stainable antibodies in titers considered to be significant developed in a few cases. Possible reasons for these responses are: 1) that there were undetected instances of cross infection in addition to the one known (Case 102 , Table II) ; 2) that the denatured antigen in 
the autoclaved inoculum was sufficient to evoke an immune response; and 3) that the sensitivity of the fluorescent-stainable antibody test as performed was too great. No data are available to test the first two hypotheses; limited experimental data have been accumulated to test the third possibility. By determining the fluorescent-stainable antibody titers simultaneously in multiple aliquots of the same serum, it was found that a variation by chance of 2 tubes (fourfold) would occur less than once in 20 times (28). This suggests that the responses seen in the control group are significant. The mechanism of these responses remains unexplained.

Not all of the patients with primary atypical pneumonia developed fluorescent-stainable antibody responses, including some considered to have had severe disease. It is possible that the negative reactions could be explained by loss of antibody through deterioration of the specimens. Another possible explanation for the negative reactions was that more than one agent was transmitted in the volunteer studies, especially since the inocula were obtained by pooling material from several patients. Sera tested from four of the six donors for the second experiment revealed significant fluorescent-stainable antibody responses to Eaton's agent in two instances (Table I). Sera from the donors for the first experiment were not available for testing. Repeated attempts to isolate the responsible agent(s) from lyophilized samples of the original inocula, using eggs and a variety of tissue culture cell lines, have all been unsuccessful (28). Additionally, failure to demonstrate antibody in some patients' postinoculation sera may be related to the time they were collected. Some of the samples were obtained 2 to 3 weeks after inoculation of the volunteers, or as early as 7 days after the onset of illness (Tables I and II), and Liu has demonstrated that the maximal percentage positivity of sera for fluorescent-stainable antibody may not occur until the fourth week of illness (5).

Some of the deficiencies in this series may be negated by appraisal of the results in terms of those that might be anticipated in the transmission of respiratory disease to human subjects. Table VII summarizes the results of several studies from the literature in which agents of known pathogenicity were employed. The over-all illness rate of 73.8 per cent in the primary atypical pneumonia experiments compares favorably with those of transmission studies in which Asian influenza virus (29), Myxovirus para-influenza 1 (30), and a variety of adenovirus types (31) have been used. A comparison of the serologic data from these various studies reveals that the percentage of significant fluorescent-stainable antibody responses approaches those of para-influenza 1 neutralization and Asian influenza virus hemagglutination inhibition; it is in excess of the percentages of complement-fixation responses illustrated.

An association between fluorescent-stainable

TABLE VII

Comparison of the primary atypical pneumonia transmission experiments to several other volunteer studies

\begin{tabular}{|c|c|c|c|c|c|c|c|}
\hline \multirow[b]{2}{*}{ Agents employed } & \multirow[b]{2}{*}{ Ref. } & \multirow[b]{2}{*}{ Volunteers } & \multirow{2}{*}{\multicolumn{2}{|c|}{$\begin{array}{l}\text { Volunteers } \\
\text { developing } \\
\text { illness* }\end{array}$}} & \multicolumn{3}{|c|}{ Volunteers' serologic responses (4-fold or $>$ ) } \\
\hline & & & & & Test & & \\
\hline ? Eaton agent & $(16)$ & no. & $\begin{array}{c}n o . \\
31\end{array}$ & $\begin{array}{c}\% \\
73.8\end{array}$ & $\begin{array}{l}\text { Fluorescent-stainable } \\
\text { antibody } \\
\text { Cold hemagglutinins }\end{array}$ & $\begin{array}{l}n o . \\
28 \\
18\end{array}$ & $\begin{array}{c}\% \\
66.6 \\
42.8\end{array}$ \\
\hline Asian influenza & $(28)$ & 23 & 18 & 78.3 & $\begin{array}{l}\text { Hemagglutination- } \\
\text { inhibition }\end{array}$ & 16 & 69.6 \\
\hline Para-influenza 1 & $(29)$ & 32 & 18 & 56.3 & $\begin{array}{l}\text { Virus neutralization } \\
\text { Hemagglutination- } \\
\text { inhibition } \\
\text { Complement fixation }\end{array}$ & $\begin{array}{l}22 \\
18 \\
14\end{array}$ & $\begin{array}{l}68.8 \\
56.3 \\
43.8\end{array}$ \\
\hline $\begin{array}{l}1,4 \text { and } 5 \\
1,2 \text { and } 3 \\
1-6\end{array}$ & & $\begin{array}{r}91 \\
168 \\
100\end{array}$ & $\begin{array}{l}55 \\
73 \\
38\end{array}$ & $\begin{array}{l}60.4 \\
43.5 \\
38.0\end{array}$ & $\begin{array}{l}\text { Complement fixation } \\
\text { Complement fixation } \\
\text { Complement fixation }\end{array}$ & $\begin{array}{l}45 \\
72 \\
36\end{array}$ & $\begin{array}{l}49.5 \\
42.9 \\
52.9\end{array}$ \\
\hline
\end{tabular}

* Clinical illness according to the criteria of the study concerned. 
antibody responses to Eaton's agent and some cases of primary atypical pneumonia has been established (5-7). The specificity of the reaction is suggested by its absence in limited series of tests using sera from patients with psittacosis, $Q$ fever, adenovirus infections, influenza, and para-influenza 1 and 3 infections $(5,7)$. The incidence of fluorescent-stainable antibodies in the general population appears to be much greater, however, than the occurrence of primary atypical pneumonia. Figures as high as 40 per cent positive reactions in collections of sera have been reported by Cook (6) and Chanock (7) and their co-workers. In the small sampling of adult males in 1944 that has been presented, 17 of the 70 men ( 24.3 per cent) had pre-existing antibody titers of 10 or greater. If the Eaton agent indeed played a role in the volunteer experiments analyzed above, it appears that it may also be associated with an undifferentiated minor respiratory illness and with subclinical disease, which offers an explanation for the apparently widespread occurrence of these fluorescent-stainable antibodies. That a spectrum of disease may be associated with the agent(s) of primary atypical pneumonia has been suggested in epidemiologic studies performed by a number of investigators $(26,32-35)$.

\section{SUMMARY}

Preserved sera from 70 volunteers participating in two primary atypical pneumonia transmission experiments were examined for fluorescent-stainable antibodies to the Eaton agent. Fluorescentstainable antibody responses were associated with cases of primary atypical pneumonia and through a spectrum of disease ranging down to apparent subclinical infection. In contrast, rises of cold hemagglutinins and streptococcus MG agglutinins were limited for the most part to patients with atypical pneumonia and were influenced by the severity of the disease. The explanation of fluorescent-stainable antibody responses in those who had no illness or had minor respiratory illness is not clear; they may represent unapparent or mild infection with the Eaton agent, or they may reflect nonspecific factors as yet unknown. It is concluded that the data presented indicate an association of the Eaton agent with disease in the volunteers studied, although the identity of the agent transmitted could not be determined di- rectly. These results cannot be interpreted as proof of the etiological role of the Eaton agent in primary atypical pneumonia until the exact specificity of the reaction between the agent and fluorescent-stainable antibodies has been established.

\section{ACKNOWLEDGMENT}

The authors are indebted to Drs. M. H. Kaplan, C. Liu, and A. S. Littell for their assistance in these studies.

\section{REFERENCES}

1. Eaton, M. D., Meiklejohn, G., van Herick, W., and Talbot, J. C. An infectious agent from cases of atypical pneumonia apparently transmissible to cotton rats. Science 1942, 96, 518.

2. Eaton, M. D., Meiklejohn, G., and van Herick, W. Studies on the etiology of primary atypical pneumonia. A filterable agent transmissible to cotton rats, hamsters, and chick embryos. J. exp. Med. 1944, 79, 649.

3. Liu, C. Studies on primary atypical pneumonia. I. Localization, isolation, and cultivation of a virus in chick embryos. J. exp. Med. 1957, 106, 455.

4. Coons, A. H., and Kaplan, M. H. Localization of antigen in tissue cells. II. Improvements in a method for the detection of antigen by means of fluorescent antibody. J. exp. Med. 1950, 91, 1.

5. Liu, C., Eaton, M. D., and Heyl, J. T. Studies on primary atypical pneumonia. II. Observations concerning the development and immunological characteristics of antibody in patients. J. exp. Med. 1959, 109, 545.

6. Cook, M. K., Chanock, R. M., Fox, H. H., Huebner, R. J., Buescher, E. L., and Johnson, R. T. Role of Eaton agent in disease of lower respiratory tract. Evidence for infection in adults. Brit. med. J. 1960, 1, 905.

7. Chanock, R. M., Cook, M. K., Fox, H. H., Parrott, R. H., and Huebner, R. J. Serologic evidence of infection with Eaton agent in lower respiratory illness in childhood. New Engl. J. Med. 1960, 262, 648.

8. Dingle, J. H., and Jordan, W. S., Jr. Primary atypical pneumonia in Viral and Rickettsial Infections of Man, 3rd ed., T. M. Rivers and F. L. Horsfall, Jr., Eds. Philadelphia, Lippincott, 1959, p. 600.

9. Horsfall, F. L., Jr. Primary atypical pneumonia. Ann. intern. Med. 1947, 27, 275.

10. Curnen, E. C., Mirick, G. S., Ziegler, J. E., Jr., Thomas, L., and Horsfall, F. L., Jr. Studies on primary atypical pneumonia. I. Clinical features and results of laboratory investigations. J. clin. Invest. 1945, 24, 209.

11. Thomas, L., Curnen, E. C., Mirick, G. S., Ziegler, J. E., Jr., and Horsfall, F. L., Jr. Complement fixation with dissimilar antigens in primary atyp- 
ical pneumonia. Proc. Soc. exp. Biol. (N. Y.) 1943, 52, 121.

12. Eaton, M. D., and Corey, M. Complement-fixation in human pneumonitis with group-reactive virus antigens. Proc. Soc. exp. Biol. (N. Y.) 1942, 51, 165.

13. Finland, M., Peterson, O. L., Allen, H. E., Samper, B. A., and Barnes, M. W. Cold agglutinins. II. Cold isohemagglutinins in primary atypical pneumonia of unknown etiology with a note on the occurrence of hemolytic anemia in these cases. J. clin. Invest. 1945, 24, 458.

14. Finland, M., Samper, B. A., and Barnes, M. W. Cold agglutinins. VI. Agglutinins for an indifferent streptococcus in primary atypical pneumonia and in other conditions and their relation to cold isohemagglutinins. J. clin. Invest. 1945, 24, 497.

15. Thomas, L., Mirick, G. S., Curnen, E. C., Ziegler, J. E., Jr., and Horsfall, F. L., Jr. Studies on primary atypical pneumonia. II. Observations concerning the relationship of a non-hemolytic streptococcus to the disease. J. clin. Invest. 1945, 24, 227.

16a. Commission on Acute Respiratory Diseases. The transmission of primary atypical pneumonia to human volunteers. I. Experimental methods. Bull. Johns Hopk. Hosp. 1946, 79, 97.

b. Ibid. II. Results of inoculation, p. 109.

c. Ibid. III. Clinical features, p. 125.

d. Ibid. IV. Laboratory studies, p. 153.

17. Eaton, M. D., Meiklejohn, G., van Herick, W., and Corey, M. Studies on the etiology of primary atypical pneumonia. II. Properties of the virus isolated and propagated in chick embryos. J. exp. Med. 1945, 82, 317.

18. Jordan, W. S., Jr., Albright, R. W., McCain, F. H., and Dingle, J. H. Clinical variations in primary atypical pneumonia. Amer. J. Med. 1951, 10, 3.

19. Coons, A. H. Fluorescent antibody methods in General Cytochemical Methods, J. F. Danielli, Ed. New York, Academic Press, 1958, vol. I, p. 399.

20. Riggs, J. L., Seiwald, R. J., Burckhalter, J. H., Downs, C. M., and Metcalf, T. G. Isothiocyanate compounds as fluorescent labeling agents for immune serum. Amer. J. Path. 1958, 34, 1081.

21. Marshall, J. D., Eveland, W. C., and Smith, C. W. Superiority of fluorescein isothiocyanate (Riggs) for fluorescent-antibody technic with a modification of its application. Proc. Soc. exp. Biol. (N. Y.) $1958,98,898$.
22. Weller, T. H., and Coons, A. H. Fluorescent antibody studies with agents of varicella and herpes zoster propagated in vitro. Proc. Soc. exp. Biol. (N. Y.) 1954, 86, 789.

23. Snedecor, G. W. Statistical Methods Applied to Experiments in Agriculture and Biology, 5th ed. Ames, Iowa State College Press, 1956, Section 5.10, p. 118.

24. Liu, C. Studies on primary atypical pneumonia. III. A factor in normal serum which enhances the reaction between PAP virus and convalescent serum. J. exp. Med. 1961, 113, 111.

25. Liu, C. Personal communication.

26. Eaton, M. D., and van Herick, W. Serological and epidemiological studies on primary atypical pneumonia and related acute upper respiratory disease. Amer. J. Hyg. 1947, 45, 82.

27. Eaton, M. D., van Herick, W., and Meiklejohn, G. Studies on the etiology of primary atypical pneumonia. III. Specific neutralization of the virus by human serum. J. exp. Med. 1945, 82, 329.

28. Clyde, W. A., Jr., and Denny, F. W., Jr. Unpublished data.

29. Bell, J. A., Ward, T. G., Kapikian, A. Z., Shelokov, A., Reichelderfer, T. E., and Huebner, R. J. Artifically induced Asian influenza in vaccinated and unvaccinated volunteers. J. Amer. med. Ass. 1957, $165,1366$.

30. Reichelderfer, T. E., Chanock, R. M., Craighead, J. E., Huebner, R. J., Turner, H. C., James, W., and Ward, T. G. Infection of human volunteers with type 2 hemadsorption virus. Science 1959, 128, 779.

31. Bell, J. A., Ward, T. G., Huebner, R. J., Rowe, W. P., Suskind, R. G., and Paffenbarger, R. S., Jr. Studies of adenoviruses (APC) in volunteers. Amer. J. Publ. Hlth 1956, 46, 1130.

32. Iverson, $H$. A. An epidemic of acute respiratory disease associated with atypical pneumonia. Bull. Johns Hopk. Hosp. 1943, 72, 89.

33. Campbell, T. A., Strong, P. S., Grier, G. S., III, and Lutz, R. J. Primary atypical pneumonia. A report of two hundred cases at Fort Eustis, Virginia. J. Amer. med. Ass. 1943, 122, 723.

34. Harding, H. B., and Snyder, R. A. The epidemiology of primary atypical pneumonia. A.M.A. Arch. intern. Med. 1960, 105, 217.

35. Breslow, L. Epidemic of acute respiratory disease associated with atypical pneumonia. J. clin. Invest. 1945, 24, 775. 